\title{
Research \\ Moving Toward Spatial Solutions in Marine Conservation with Indigenous Communities
}

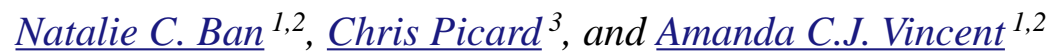

\begin{abstract}
Community and resource user support has often been declared as essential to achieving globally agreed targets for marine protection. Given that indigenous people in Canada have resource use rights, we engaged two indigenous communities in British Columbia for their views on marine planning and protected areas. We developed a three-phased approach for executing our research: building research partnerships, carrying out individual interviews, and holding community discussion sessions. Participants expressed a common goal of recovering depleted species and ensuring the sustainability of indigenous fishing. We found strong support for spatial protection measures, and significant overlaps amongst participants in the areas suggested for protection. The most common type of protection recommended by participants was the exclusion of commercial and recreational fisheries while allowing for indigenous fishing; this stands in contrast to the emphasis on strict no-take MPAs advocated in the literature. Similarities in the goal, and level and areas of protection point to a gap in conservation approaches: the conservation of important areas and resources to indigenous people, allowing the continued practice and adaptation of their culture.
\end{abstract}

Key Words: aboriginal fisheries; British Columbia; Canada; commercial fisheries; community-based conservation; indigenous communities; marine conservation; marine protected areas

\section{INTRODUCTION}

Marine protected areas (MPA) can be a valuable conservation tool to halt the decline of overexploited fish and invertebrate populations (Kelleher and Kenchington 1992, Walters 1998, Dayton et al. 2000, Halpern and Warner 2002, Worm et al. 2006) and may also enhance fisheries (McClanahan and Mangi 2000, Halpern and Warner 2002, Abesamis and Russ 2005). However, less than $0.01 \%$ of the ocean is currently protected, and the pace of establishment of new MPAs is too slow to meet international conservation commitments (World Summit on Sustainable Development 2003, Convention on Biological Diversity (CBD) 2006, Wood et al. 2007). This is a concern because people are increasingly dominating coastal ecosystems (Weinstein et al.2007) and accelerating degradation (Pauly et al. 1998, Ban and Alder 2008).

Marine protected areas selection experiences repeatedly confirm the importance of engaging those affected by the designation (Morin Dalton
2001, Kessler 2003, Helvey 2004, Drew 2005, Lundquist and Granek 2005). Indeed, social factors are often highlighted as the primary determinants of MPA success (Morin Dalton 2001, Mascia 2003, Kessler 2004, Drew 2005). In particular, MPAs affect extractive users the most, which can be commercial, recreational, subsistence, or indigenous fisheries. To prevent fishing grounds from being fished more intensively due to the establishment of MPAs, a recommendation for improving MPA success is to proportionally reduce fishing pressure elsewhere (Walters 2000, Halpern et al. 2004, Hilborn et al. 2006).

Recently, there has also been increased international recognition of the rights of indigenous peoples to resources on traditional territories, including marine resources (United Nations General Assembly 2007). Consequently, part of the challenge in establishing MPAs lies in adequately respecting such rights. In some countries, indigenous people constitute local communities as well as a level of government (e.g., Canada: Harris 2002, Australia: 
Sanders 2002, United States: Zaferatos 2004), and they may also either claim or have established rights and title to marine resources (Mulrennan and Scott 2000, Bess 2001, Davis and Jentoft 2001, Ross and Pickering 2002).

Our research focused on indigenous peoples in Canada, where they are known as First Nations. They are considered a level of government and have rights, established by common law and protected by the Canadian Constitution, to fish for food, social, and ceremonial purposes. We refer to food, social, and ceremonial fishing as indigenous or aboriginal fishing, and exclude commercial fisheries from this definition. In some cases, First Nations have confirmed a right to fish for commercial purposes. Many First Nations interpret the "social" component of fishing rights to include commercial fisheries, but the federal government disagrees. Whether or not commercial fishing is a First Nations' right is very contentious, and so far it is being addressed on a case-by-case basis as First Nations take the issue to court. Case law has also affirmed the federal and provincial governments' responsibility to meaningfully consult First Nations and accommodate their interests when making resource management decisions (Harris 2002, Houde 2007). After the R. vs. Sparrow decision, the court ruled that aboriginal rights to fish for food, social, and ceremonial purposes have priority over all other uses of the fishery (Fisheries and Oceans Canada 2008). Such fisheries are termed aboriginal fisheries, and are a separate category from commercial and recreational fisheries, authorized by communal licenses (Fisheries and Oceans Canada 2008). First Nations commonly view strict marine conservation measures, e.g., no-take MPAs, as an infringement of these rights, and are afraid that no-take MPAs would preclude them from exercising that right. Because potential infringement of rights and title are of enormous concern and part of a much larger issue than marine conservation, many First Nations have not been willing to let MPAs set a precedent of infringement. Hence, even though many First Nations have a strong conservation ethic, the issue has provided one more impediment to MPA establishment in Canada (Ayers 2005). First Nations' concerns regarding MPAs also stem from inadequate consultations (LeRoy et al. 2003), and a fear of compromising their negotiating position in the treaty process where treaties do not exist (Ayers 2005).

However, many First Nations are interested in ensuring sustainable use of the oceans because seafood continues to comprise an integral part of First Nations' culture and economy (Garibaldi and Turner 2004), and because they still rely on traditional foods for sustenance (Weinstein and Morrell 1994). First Nations communities are, of course, also faced with the universal challenges of balancing economic development with conservation.

There is some precedent in Canada to incorporate the sustainable use of marine resources by indigenous people into MPAs. In Canada's Arctic, the Beaufort Sea Beluga Management Plan includes a protection zone that permits traditional harvest of belugas by Inuit. Other activities are either excluded, or allowed only if they do not have a deleterious effect on belugas (Fast et al. 2001). These zones are currently being considered as MPAs under the Oceans Act, in order to support the beluga management plan (Fast et al. 2001). The situation in the Arctic differs from British Columbia (BC), however, in that there are comprehensive land claim agreements in the Canadian North (Berkes et al. 2007). Because of this, governance regimes and responsibilities are well defined. This is not the case in $\mathrm{BC}$, where treaties have not been settled.

The purpose of this research was to develop and test a framework to integrate the preferences and concerns of First Nations into the site selection of potential MPAs, summarize their views, and document constraints and challenges. In particular, we address the following questions: (1) What kind of protection would they like to see and where, and how might this affect commercial fisheries? (2) How can their views potentially help to advance marine management, and are there any gaps in current marine conservation approaches? (3) What are the limitations of their suggestions? Our research was undertaken in partnership with the Gitga' at and Huu-ay-aht First Nations. We use the traditional territories of these First Nations as our case studies. Given the sociopolitical context for our work, we need to emphasize that our study is academic; the resulting information was shared with the First Nations partners and will only be used for planning purposes if the First Nations partners decide to do so.

Both study areas have had some involvement in conservation issues, although primarily terrestrial. Recently, the Gitga'at First Nation has been involved in the creation of the Great Bear Rainforest. The Gitga' at and other First Nations on BC's North and Central coasts have recently established numerous conservancies through 
integrated planning of BC's coastal lands working with the BC government. Several of the new land conservancies in Gitga'at territory also include coastal and foreshore areas. However, marine fish harvesting activities are not explicitly included in these conservancies as they are not under the provincial government's jurisdiction. Gitga' at are currently developing joint management plans for these conservancies with the provincial government. The Huu-ay-aht's territory encompasses part of Pacific Rim National Park Reserve, and hence they have had some involvement in a national park. Generally, however, the Huu-ay-aht First Nation has been less involved in conservation issues recently compared with the Gitga' at First Nation. Much of the Huu-ay-aht's efforts have been on negotiating a treaty, which is currently in the final stages of approval (Indian and Northern Affairs Canada 2007).

Although fisheries spatial management measures exist within both traditional territories, neither have MPAs. Some parks exist that have boundaries that extend into the marine environment (e.g., Pacific Rim National Park Reserve), but none are presently managed for marine conservation. Rockfish conservation areas have been established within both case studies, but these were designated to protect a guild of species, rather than marine resources more generally. From the perspective of marine conservation generally, spatial management of marine resources for conservation is limited at present in both case studies.

\section{METHODS}

To carry out our research, we focused on two indigenous groups in British Columbia, Canada. The Gitga' at First Nation is a Tsimshian First Nation on the north coast of BC. The Huu-ay-aht First Nation is one of the Nuu-chah-nulth First Nations, located on the west coast of Vancouver Island. These First Nations were selected as case studies because of their interest in partnering in this research and because they differ in their participation in the treaty process: Gitga' at First Nation has temporarily suspended its involvement in the treaty process ( http://gitgaat.net/contact/treatyoffice.htm), whereas the Huu-ay-aht people have ratified their treaty (ht tp://www.maanulth.ca/about fn huu-ay-aht.asp).

The two First Nations also provide contrasts in the accessibility of the main communities: the Gitga'at First Nation's community of Hartley Bay is more remote, accessible by a 4-hr boat ride or by float plane (weather permitting); the Huu-ay-aht First Nation's town of Anacla is accessible by logging road, and is located near the small town of Bamfield.

Although the First Nations are located hundreds of kilometers apart, they exhibit similar histories and social structures. All First Nations in British Columbia experienced rapid change following the arrival of Europeans (Harris 2002). Although European customs and foods have been incorporated into daily life, many indigenous customs continue to be practiced, and the clans, or house groups, remain as an important component of village organization (Menzies et al. 2001). Fisheries and the collection of other seafoods was essential for survival before the arrival of Europeans, and as industrial fisheries expanded, many First Nations people made a living from various aspects of commercial fisheries (Harris 2001). As fisheries declined and ownership of licenses became more centralized, many First Nations lost access to commercial fishing opportunities (Harris 2001). However, as with other coastal First Nations communities, both the Gitga' at and Huu-ay-aht communities continue to use seafood in their diet and as a fundamental part of their culture and economy.

We developed a framework to integrate the preferences and concerns of First Nations into marine conservation. The framework consisted of three phases: (1) establishment of research collaborations, (2) semi-structured individual interviews with First Nations community members, and (3) feedback from the communities about marine conservation preferences obtained through the interviews (Fig. 1). Phase 2 and 3 focused on the goals for the marine territories and in particular examined issues affecting the area, and preferred management solutions. Phase 2 built on components of issue-action analysis through interviews by identifying issues and the associated actions that could be taken to address them (Salm and Clark 2000). Phase 3 approximated consensual planning through community meetings (Innes 1996, Kay and Alder 2005). The framework we used differs from others (e.g., as reviewed in Kessler (2004) and Brody et al. (2003)) because we interviewed individuals in addition to holding community meetings. Also, our research required participants to use their knowledge to make management recommendations, rather than collecting traditional ecological knowledge per se (Berkes et al. 2000, Drew 2005). 
Fig. 1. Framework for eliciting community preferences for spatial management options.

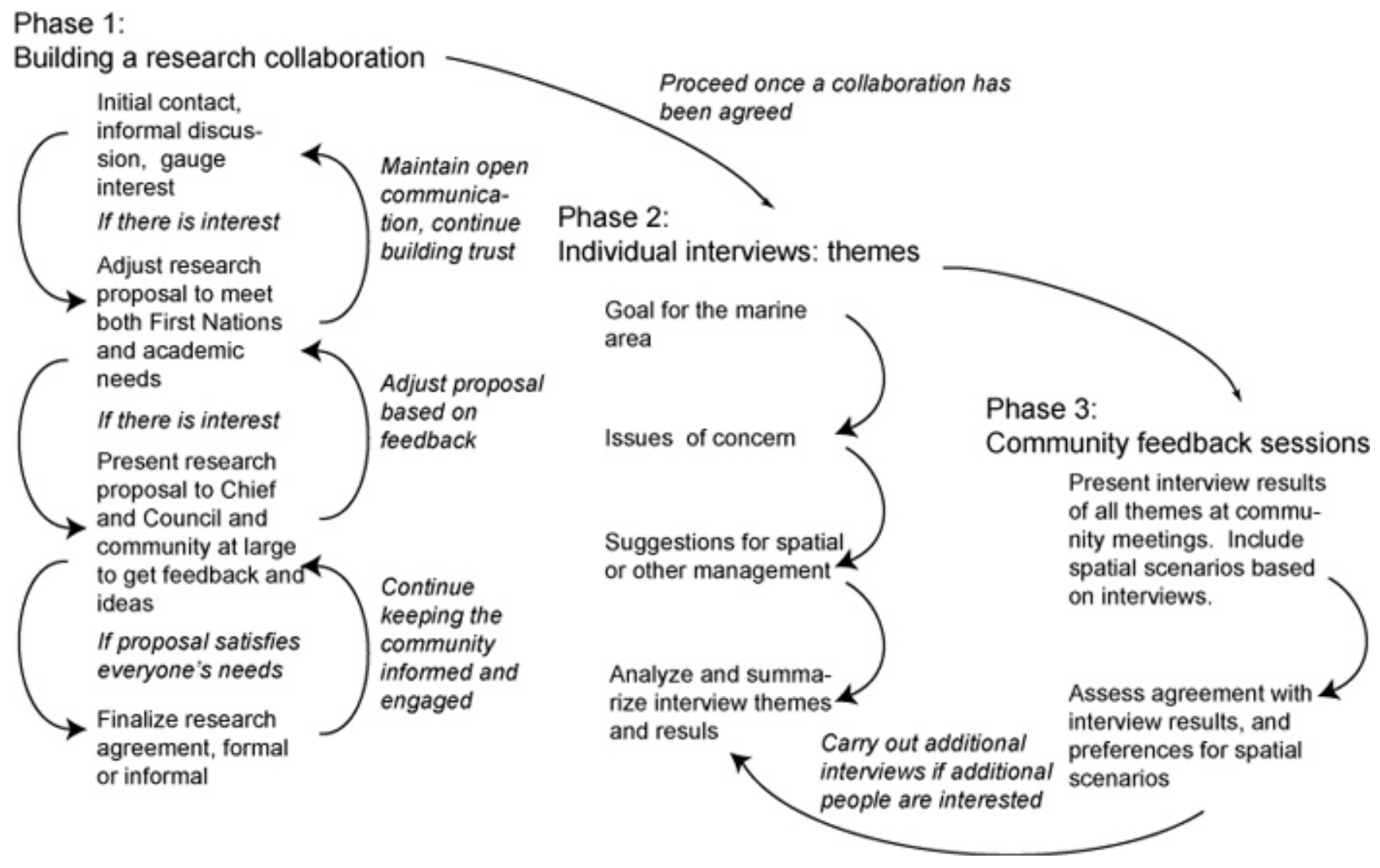

\section{Phase 1: Establishment of Research Collaborations}

To establish research collaborations, we started informal conversations with community contacts responsible for marine and/or fisheries management within the territories. After initial interest was established, we worked together to formulate the research approach, and took the proposal to the chief and council (the First Nations governance body) for their approval.

\section{Phase 2: Semi-structured Individual Interviews with First Nations Community Members}

Interviews with members of the First Nations comprised the core of the research project. We used a snowball approach (Goodman 1961) to focus on people who are, or have been, active users of marine resources, and/or who have a particular depth of knowledge about the marine environment. We chose our focus because these people would be most affected if management changes were implemented. We stratified our snowball approach to ensure that we interviewed participants from all clans. We interviewed 20 self-identified Gitga'at marine resource users and 19 in Huu-ay-aht territory. We carried out semi-structured interviews in November 2005, February-March 2006, and November 2006 with Gitga'at members, and February to June 2007 with Huu-ay-aht members. In the Gitga' at territory, interviews were carried out in Hartley Bay $(n=11)$ and in Prince Rupert $(n=9)$, where about two-thirds of Gitga' at members currently live. In the Huu-ayaht territory, interviews were focused in Anacla ( $n$ $=17$ ), with a couple of interviews in Port Alberni. We interviewed people from a range of age groups, with some younger (ages 18 to 35) participants (Gitga' at $n=2$, Huu-ay-aht $n=4$ ), most ranging 
from ages 36 to 60 (Gitga' at $n=13$, Huu-ay-aht $n$ $=11$ ), and some over the age of 60 (Gitga' at $n=5$, Huu-ay-aht $n=4$ ). Because there is a traditional male gender bias in people who are out on the water, most participants were male (Gitga' at $n=15$, Huuay-aht $\mathrm{n}=17$ ).

All interviews included the same themes: the participant's goal(s) for the marine component of the territory, issues of concern, suggestions for spatial and other management, general opinions about no-take MPAs, and the participant's history of marine involvement (i.e., indigenous, recreational, and/or commercial fishing; other extraction; processing, etc.). Responses to these questions were unprompted (hereafter referred to as unprompted responses). This means that we did not provide a list of possible answers to our questions. The style of the interviews was conversational, and we did ask probing questions without providing potential answers. Interviews lasted between half an hour and $4 \mathrm{hr}$, and most were one-on-one, with four interviews in which two participants were interviewed at the same time. We kept detailed notes during the interviews.

The core of the interview process focused on participants' suggestions for spatial protection measures. In a map-based process, participants drew freeform polygons on tracing paper overlaying nautical charts of the study region to indicate their suggested areas for protection (Ardron 2005). Participants were comfortable reading nautical charts and using them to indicate their preferences. The nautical charts encompassed the entire marine portion of the Gitga' at and Huu-ay-aht territories. We did not specify the extent of the traditional territories during the interviews, but rather let participants decide where they felt comfortable suggesting protection measures. There are many areas of overlap and/or contention with neighboring First Nations.

Participants were also asked what kind of protection they envisioned for each of the polygons they drew. All information was stored using a Microsoft Access ${ }^{\circledR} 2003$ database and analyzed using ESRI's ArcGIS ${ }^{\circledR}$ version 9.1. Spatial analysis focused on the management options drawn by participants. We combined polygons from each management suggestion to depict the overlap of suggested areas amongst participants. We created several management scenarios of the most commonly suggested type of protection to represent a range of options based on the overlap of polygons. We used the Getis-Ord General G statistic (Getis and Ord 1992) to test the congruence of areas selected by participants. We also asked participants about their opinion of no-take MPAs.

\section{Phase 3: Feedback from the Communities}

Following individual interviews, we held open community meetings (November 2006 in Gitga' at territory, November 2007 in Huu-ay-aht territory) to present findings and receive feedback. All community members were invited to attend, and participants self-selected their attendance. Interview participants and others attended these meetings, including people from a range of age groups and positions within the community. Meetings allowed people to see the aggregated results of interviews, and to voice their opinions on the areas marked by interview participants. Before discussing the results, we asked participants to record (individually and anonymously) their agreement with the management scenarios on a feedback form, using a five-point Likert scale (Matell and Jacoby 1971). The form also asked them to check a box if they had been interviewed for our study. Once the feedback forms had been collected, we discussed the scenarios derived from interviews, with participants providing comments on potential protected areas that had been missed, were superfluous, or with which they disagreed. We incorporated these changes into the GIS file to most closely approximate the goal that emerged from the meetings. We then calculated the area covered by these maps of preferred protected areas. For the Gitga'at territory, we analyzed the proportion of traditional fishing areas encompassed by the map of preferred protected areas. We did not have traditional fishing locations for the Huu-ay-aht territory.

\section{Possible Impacts of Community Zoning on a Key Other Stakeholder-Commercial Fisheries}

We then analyzed how community-chosen protected areas might impact commercial fisheries. We obtained spatial catch information from 19932005 from Fisheries and Oceans Canada in a summarized form of either 4 X $4 \mathrm{~km}$ or $10 X 10 \mathrm{~km}$ grid cells. We received these data for 11 commercial fisheries found in the study areas. Spatial data for 
other fisheries were not available. We calculated the mean catch in pounds per year for each fishery. We scaled catch values to the suggested protected areas, which might be less than cell size, thereby assuming that catches were distributed homogeneously within each grid cell. Spatial data on sports fishing catches are not collected by the government so the analysis was limited to commercial fisheries data.

\section{RESULTS}

Participants in our study were associated with a range of resource extraction and management activities. Most participants in the Gitga'at case study have been involved in commercial fisheries $(75 \%)$, and some were seasonally employed by sports fishing lodges $(10 \%)$ or involved in other tourism activities (5\%). Similarly, in the Huu-ayaht case study, most participants $(79 \%)$ have been involved in commercial fisheries, whereas some were involved in recreational fisheries $(16 \%)$, shellfish aquaculture $(11 \%)$, or stream restoration $(11 \%)$.

\section{Goal of the Area}

Participants' goals of what they would like to see in their territory (unprompted responses) were remarkably congruent within the communities and between case study areas. The most commonly stated priority in Gitga'at territory $(85 \%)$ was to ensure that food fisheries were protected for present and future generations, with the next goal being recovery of depleted species $(80 \%)$, with particular reference to abalone (Haliotis kamtschatkana) (35\%). In Huu-ay-aht territory, the order was reversed, with recovery of depleted species being the most common goal (95\%) and food fisheries the next priority (64\%). Other priorities expressed were a desire for co-management of activities that take place in the territory, and additional economic opportunities, including commercial fisheries. In both communities, participants commented on declines in the abundance of species. In particular, many participants noted decreases in the abundance of salmon (Oncorhynchus spp.), and groundfish, especially rockfish (Sebastes spp.), herring (Clupea pallasii), eulachon (Thaleichthys pacificus), and halibut (Hippoglossus stenolepis).

\section{Issues of Concern}

In both communities, commercial and recreational fisheries were a concern because of the observed environmental changes due to biomass extraction (Table 1). Other issues raised included illegal fishing, the environmental impacts associated with tourism, and a frustration at the waste of bycatch with quota regulations. Issues unique to Gitga'at territory included potential future impacts of a proposed pipeline and associated oil tanker traffic. In Huu-ay-aht territory, the anticipated decline of shellfish due to increasing abundance of sea otters (Enhydra lutris) was a concern.

\section{Results from Individual Interviews: Suggestions for Spatial Protection Measures}

We found strong agreement amongst participants in the suggested types of protection. The vast majority of participants suggested areas that should exclude either commercial fishing or recreational fishing, or both (Table 2), while allowing indigenous exploitation. Most participants did not provide details on which commercial fisheries should be allowed or excluded. Rather, most participants suggested the exclusion of commercial fisheries in general. Similarly, participants did not distinguish between recreational fishing from sport fishing lodges and individual sport fishermen, instead suggesting the exclusion of recreational fishing in general. A few people suggested no fishing zones or other types of areas. On average, each person in Gitga'at territory selected 21 areas for protection (range 7 to 38 ), comprising $6.2 \%$ (range $2 \%$ to $21 \%$ ) of the claimed marine territory. In Huu-ay-aht territory, each participant suggested an average of four areas for protection (range 1 to 14), comprising $3.6 \%$ (range $<1 \%$ to $27 \%$ ) of the claimed territory.

There was a significant degree of overlap amongst community members for suggested areas to exclude from commercial fishing, recreational fishing, or both (Figs. 2 and 3). The Getis-Ord General G spatial statistic indicated less than $1 \%$ likelihood that the pattern for each of the three management types (within management measures amongst respondents) could be the result of chance for the Gitga'at study area. The same applies to the Huuay-aht study area for the "no commercial fishing suggestions," and less than $10 \%$ likelihood that the pattern is a result of chance for the other two 
Table 1. Proportions of the participants who raised particular marine issues during semi-structured interviews in two First Nations' territories (unprompted responses).

\begin{tabular}{|c|c|c|c|c|}
\hline \multirow[b]{2}{*}{ Type of issue } & \multicolumn{2}{|c|}{ Gitga'at territory $(n=20)$} & \multicolumn{2}{|c|}{ Huu-ay-aht territory $(n=19)$} \\
\hline & Proportion & $\begin{array}{c}\text { Ongoing or } \\
\text { potential/anticipated } \\
\text { issues* }\end{array}$ & Proportion & $\begin{array}{l}\text { Ongoing or potential/ } \\
\text { anticipated issues* }\end{array}$ \\
\hline $\begin{array}{l}\text { Population declines due to } \\
\text { commercial fishing }\end{array}$ & $80 \%$ & Ongoing & $68 \%$ & Ongoing \\
\hline $\begin{array}{l}\text { Population declines due to } \\
\text { recreational fishing }\end{array}$ & $75 \%$ & Ongoing & $68 \%$ & Ongoing \\
\hline $\begin{array}{l}\text { Population declines due to illegal } \\
\text { fishing }\end{array}$ & $45 \%$ & Ongoing & $5 \%$ & Ongoing \\
\hline $\begin{array}{l}\text { Potential environmental damage } \\
\text { of the proposed pipeline and } \\
\text { associated oil tanker traffic (e.g., } \\
\text { oil spills) }\end{array}$ & $45 \%$ & Anticipated & N/A & \\
\hline $\begin{array}{l}\text { Environmental degradation } \\
\text { associated with tourism }\end{array}$ & $30 \%$ & Ongoing & $37 \%$ & Ongoing \\
\hline $\begin{array}{l}\text { Habitat damage caused by } \\
\text { logging and its effects in the } \\
\text { ocean }\end{array}$ & $25 \%$ & Ongoing & $11 \%$ & Ongoing \\
\hline $\begin{array}{l}\text { Population declines due to } \\
\text { bycatch, and wastefulness of } \\
\text { bycatch regulations }\end{array}$ & $20 \%$ & Ongoing & $0 \%$ & \\
\hline $\begin{array}{l}\text { Environmental degradation due to } \\
\text { finfish farming }\end{array}$ & $20 \%$ & Anticipated & $16 \%$ & Ongoing \\
\hline $\begin{array}{l}\text { Unpredictable changes due to } \\
\text { climate change }\end{array}$ & $20 \%$ & Ongoing & $5 \%$ & Ongoing \\
\hline Mismanagement of fisheries & $20 \%$ & Ongoing & $32 \%$ & Ongoing \\
\hline $\begin{array}{l}\text { Uncertainty in seismic testing on } \\
\text { marine life }\end{array}$ & $20 \%$ & Anticipated & N/A & \\
\hline $\begin{array}{l}\text { Environmental degradation due to } \\
\text { oil and gas exploration }\end{array}$ & $15 \%$ & Anticipated & $0 \%$ & \\
\hline Habitat damage due to anchoring & $5 \%$ & Ongoing & $0 \%$ & \\
\hline Commercialization of seaweed & $5 \%$ & Anticipated & $0 \%$ & \\
\hline $\begin{array}{l}\text { Population declines due to First } \\
\text { Nations fishing }\end{array}$ & $5 \%$ & Ongoing & $16 \%$ & Ongoing \\
\hline $\begin{array}{l}\text { Environmental impacts of } \\
\text { pollution }\end{array}$ & $5 \%$ & Ongoing & $16 \%$ & Ongoing \\
\hline
\end{tabular}




\begin{tabular}{lccc}
\hline $\begin{array}{l}\text { Invertebrate declines due to } \\
\text { increasing abundance of sea otters }\end{array}$ & $0 \%$ & $26 \%$ & Anticipated \\
$\begin{array}{l}\text { Fish population declines due to } \\
\text { increases in seals and sea lion }\end{array}$ & $0 \%$ & $21 \%$ & Ongoing \\
$\begin{array}{l}\text { Habitat damage due to trawling } \\
\begin{array}{l}\text { Changes in foodweb interactions } \\
\text { due to invasive species }\end{array}\end{array}$ & $0 \%$ & $16 \%$ & Ongoing \\
$\begin{array}{l}\text { Genetic contamination due to } \\
\text { hatcheries }\end{array}$ & $0 \%$ & $5 \%$ & Ongoing \\
\hline
\end{tabular}

* Ongoing refers to issues that are currently taking place and are expected to continue into the future. Potential or anticipated refer to issues that are not yet occurring, but will potentially appear in the future.

management suggestions. Some participants recognized that their suggestions for protection measures fell into areas that overlap with neighboring First Nations.

Only two people in the Gitga'at case study (and none in the Huu-ay-aht case study) suggested areas where no fishing, including aboriginal fishing, should take place. However, when asked, most participants (60\% Gitga' at, $43 \%$ Huu-ay-aht) offered no strong opinion for or against such no-take areas. The rest indicated support for the concept. Two people in the Huu-ay-aht study area opposed the idea.

\section{Results from Community Feedback Sessions}

Feedback forms and discussion at the community feedback session in the Gitga'at study area revealed that participants at the meetings $(n=21)$ preferred a scenario that covered a large portion of the territory (between scenarios in Fig. 4a, b). Using the feedback form, $83 \%$ of meeting participants gave scenario "a" the highest ranking, compared with $50 \%$ for scenario "b", $17 \%$ for scenario "c" and "d," and $33 \%$ for scenario "e". Some respondents gave multiple scenarios their highest ranking. The discussion that followed revealed that people at the meetings thought that scenario "a" was too large an area, whereas a few areas represented in "a" but not " $b$ " were seen as important for protection. The discussion mirrored the responses received on the feedback forms. The areas that were missing from " $b$ " were subsequently added to create a map that currently represented the closest approximation to the community goal for areas for protection. This map has 26 areas, each with a mean size of 2250 ha, comprising in total $7 \%$ of the marine territory of the Gitga'at First Nation, and $82 \%$ of Gitga'at traditional fishing point locations as identified by elders (Chris Picard, unpublished data). When excluding the large offshore component of Gitga' at terrritory $(5 \mathrm{~km}$ offshore from outer islands and beyond) - which few participants knew, used, or nominated - a total of $15 \%$ of Gitga' at inshore waters were selected for protection.

The feedback results were similar for the Huu-ayaht session $(n=8)$. Using the feedback form, $80 \%$ of participants gave scenario "b" the highest ranking, followed by scenario "a" and "c" as the second most popular choices. As with the Gitga' at case study, it was the larger, but not largest, of the options that was preferred. This most preferred option consists of four areas, each with a mean size of 1216 ha, comprising $0.4 \%$ of the marine territory. When excluding the offshore component, this rises to $3 \%$ of the territory. Due to inclement weather, the feedback session was not very well attended. Follow-up conversations with people unable to attend confirmed the preferences stated by participants at the meeting.

\section{Potential Impacts on Commercial Fisheries}

Our analysis of the potential impact of the suggested protected areas on commercial fisheries revealed that the commercial catches are roughly proportional to the area of the preferred protection 
Table 2. Spatial marine protection measures suggested by participants.

\begin{tabular}{lcc}
\hline \hline & $\begin{array}{c}\text { Proportion of participants who suggested this management } \\
\text { zone }\end{array}$ \\
Type of management zone & $\begin{array}{c}\text { Gitga' at territory } \\
(n=20)\end{array}$ & $\begin{array}{c}\text { Huu-ay-aht territory } \\
(n=19)\end{array}$ \\
\hline No commercial fishing & $100 \%$ & $91 \%$ \\
No recreational fishing & $100 \%$ & $64 \%$ \\
Neither recreational nor commercial fishing & $100 \%$ & $64 \%$ \\
No fishing & $14 \%$ & $18 \%$ \\
No tourism & & \\
Tourism area & $14 \%$ & $18 \%$ \\
Other & $14 \%$ & \\
\hline
\end{tabular}

areas for the whole territory (Table 3). However, some fisheries would be impacted much more than others, and we did not have spatial catch data for all fisheries. Notably, spatial information for commercial salmon and halibut was not available. These are highly mobile species, however, and therefore the corresponding fisheries may have flexibility in adjusting their fishing areas. If the First Nations decide to pursue implementation of these areas as MPAs that permit aboriginal food fishing only and reduce commercial quotas so that fishing effort is not increased outside of the preferred protection areas, then those reductions would be about proportional to the percentage of the marine territory protected. The two active Gitga'at commercial fishermen who we interviewed both indicated a willingness to avoid the preferred protection areas for their commercial fishing, should they be implemented. Both these participants suggested MPAs in areas where they currently fish commercially, noting that they could change the areas where they fish commercially.

\section{DISCUSSION}

In this research, we sought to synthesize the perspectives of indigenous people on marine conservation issues. Among participants of this study, we found a willingness to embrace spatial protection measures. The main goals for the marine territories among participants were the recovery of depleted species and sustainability of indigenous fishing; the preferred management approach was to protect areas from commercial and recreational fishing. Overall, our research revealed a gap in our current conservation efforts: areas of importance to indigenous people warrant protection that allows their continued use of those areas. However, the scientific literature places much greater emphasis on no-take MPAs, and hence additional research is needed to assess the efficacy of partial-take MPAs.

The areas most commonly identified for protection were of high importance for indigenous fishing, an activity that occurs within the context of First Nations' legally protected right to fish. Even though indigenous people have a right to fish for food, social, and ceremonial purposes in Canada, transforming that right into practice is an ongoing struggle, with a proliferation of lawsuits (Harris 2002, Houde 2007). Elsewhere in the world, indigenous people similarly struggle to be involved 
Fig. 2. Gitga' at case study, British Columbia: overlap of spatial protection zones suggested by interview participants $(n=20)$. Types of zones suggested are "a" no recreational fishing, "b" no commercial fishing, and "c" no fishing. Map "a" and "b" are similar because participants commonly drew polygons that they felt should be closed to both commercial and recreational fishing. Participants could make as many management suggestions as they wished. The areas noted on the map reflect participants' interpretations of the traditional territory.
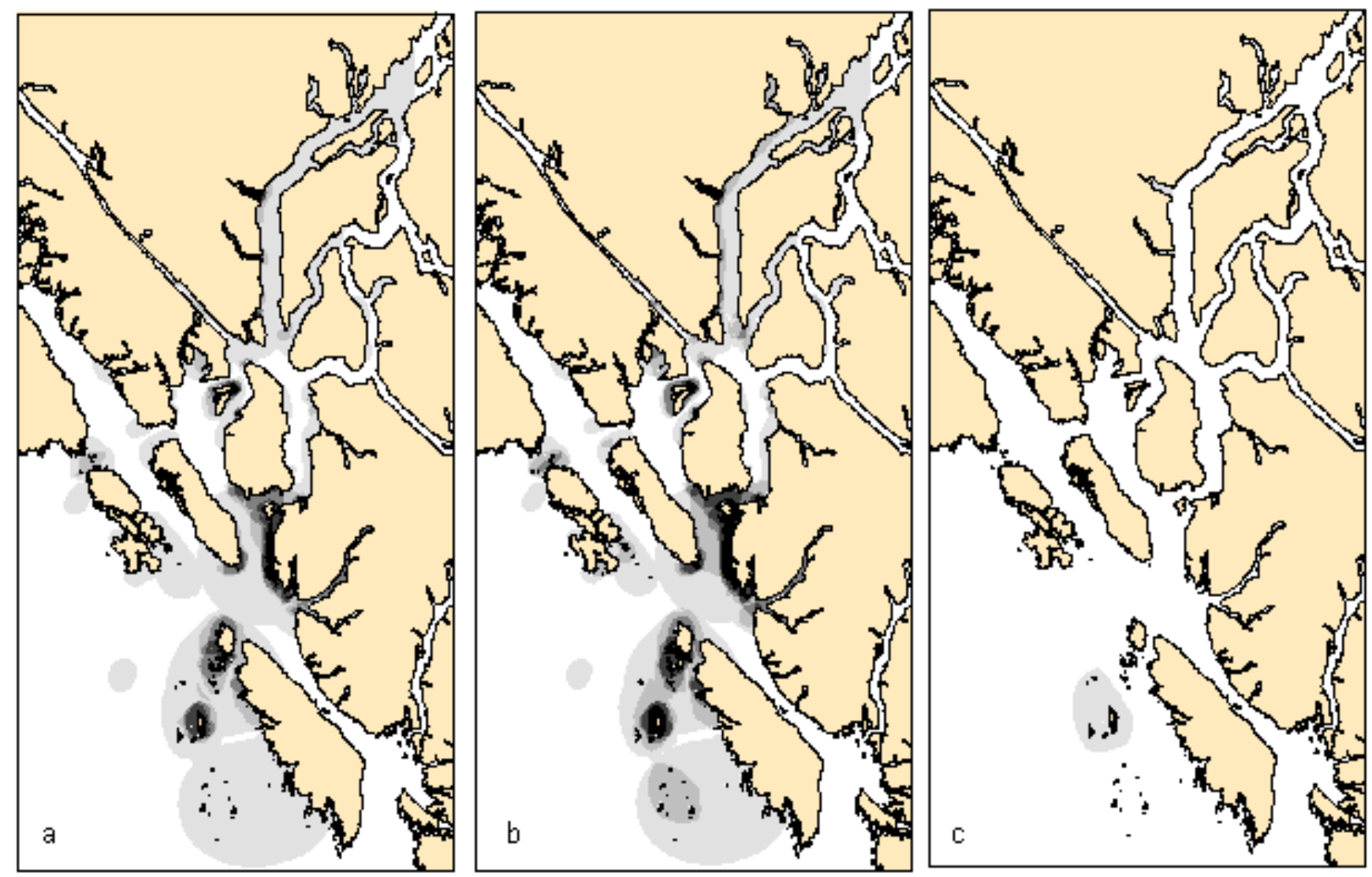

Overlap

$10 \%-25 \%$
$26 \%-40 \%$
$41 \%-55 \%$
$56 \%-70 \%$
$71 \%-100 \%$
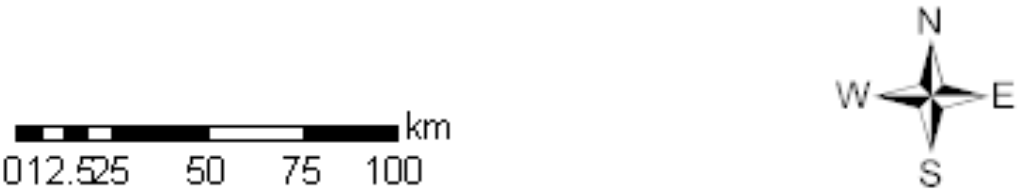
Fig. 3. Huu-ay-aht case study, British Columbia: overlap of spatial protection zones suggested by interview participants $(n=19)$. Types of zones suggested are "a" no recreational fishing, "b" no commercial fishing, and "c" neither commercial nor recreational fishing, but aboriginal fishing allowed. Map "c" shows the overlap of maps "a" and "b." Participants could suggest as many management suggestions as they wished. The areas noted on the map reflect participants' interpretations of the traditional territory.
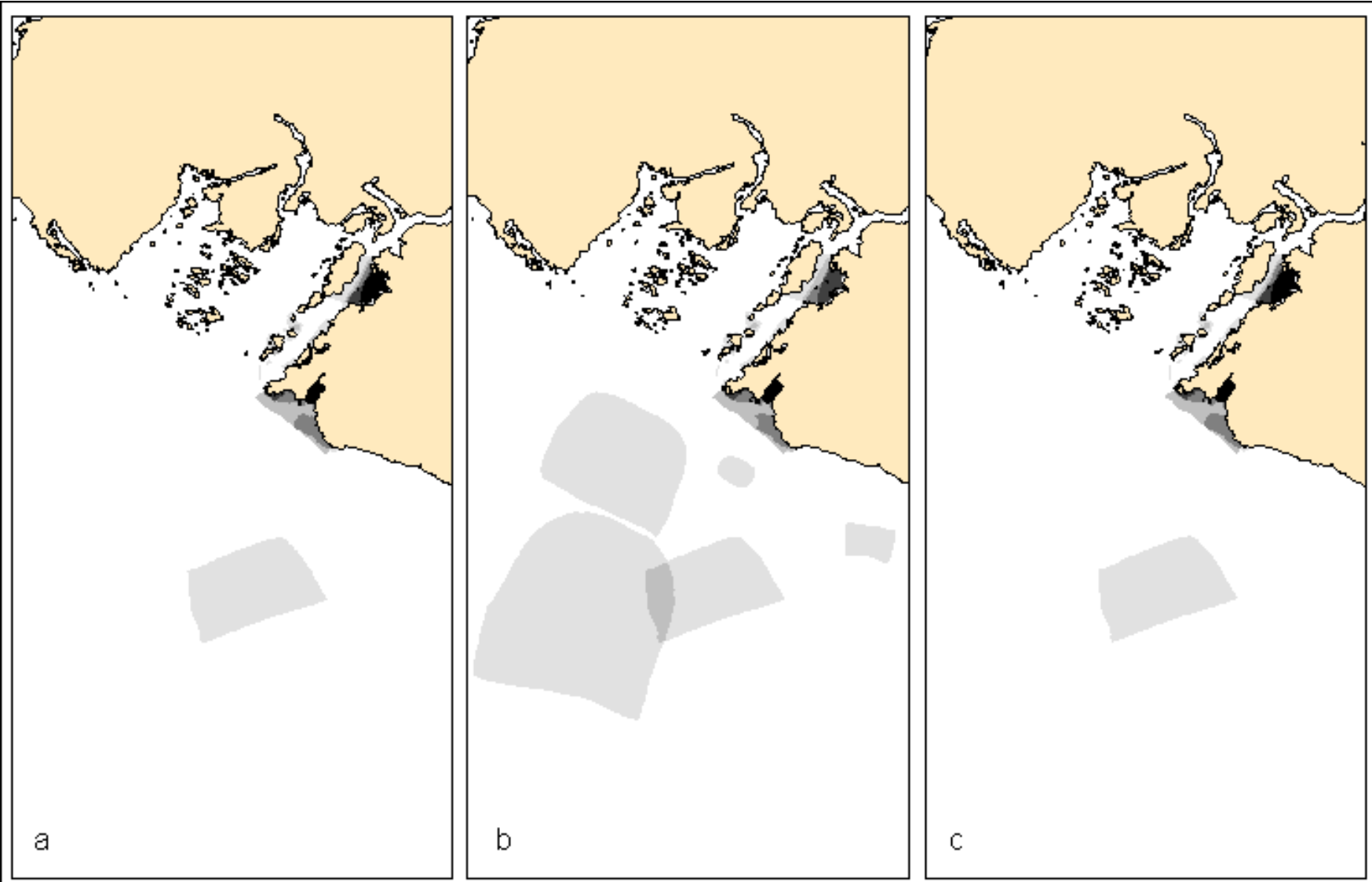

Overlap

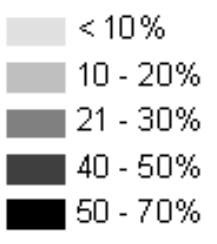

in resource extraction and management decisions within marine areas claimed as their territory (Mulrennan and Scott 2000, 2001, Bess 2001, Davis and Jentoft 2001). This makes it particularly important to incorporate indigenous perspectives into marine protection and zoning, and to create areas that are specifically established to protect indigenous fishing grounds.
The First Nations we interviewed shared the goal (within and across communities) of recovering depleted species and ensuring sustainability of traditional foods. This conservation focus was by no means a foregone conclusion. The emphasis could have been placed on, for example, economic development or commercial fishing opportunities, especially given the high level of unemployment in 
Fig. 4. Gitga' at case study: five scenarios were created from individual interviews for the most common protection type where only aboriginal rights fisheries would be allowed: "a" all areas selected by any participant; "b" areas selected by $30 \%$ of participants; "c" areas selected by $50 \%$ of participants; "d" areas selected by $70 \%$ of participants; and "e" areas selected by all participants. "f" depicts the revised preferred protected areas based on feedback meetings. The areas noted on the map reflect participants' interpretations of the traditional territory.
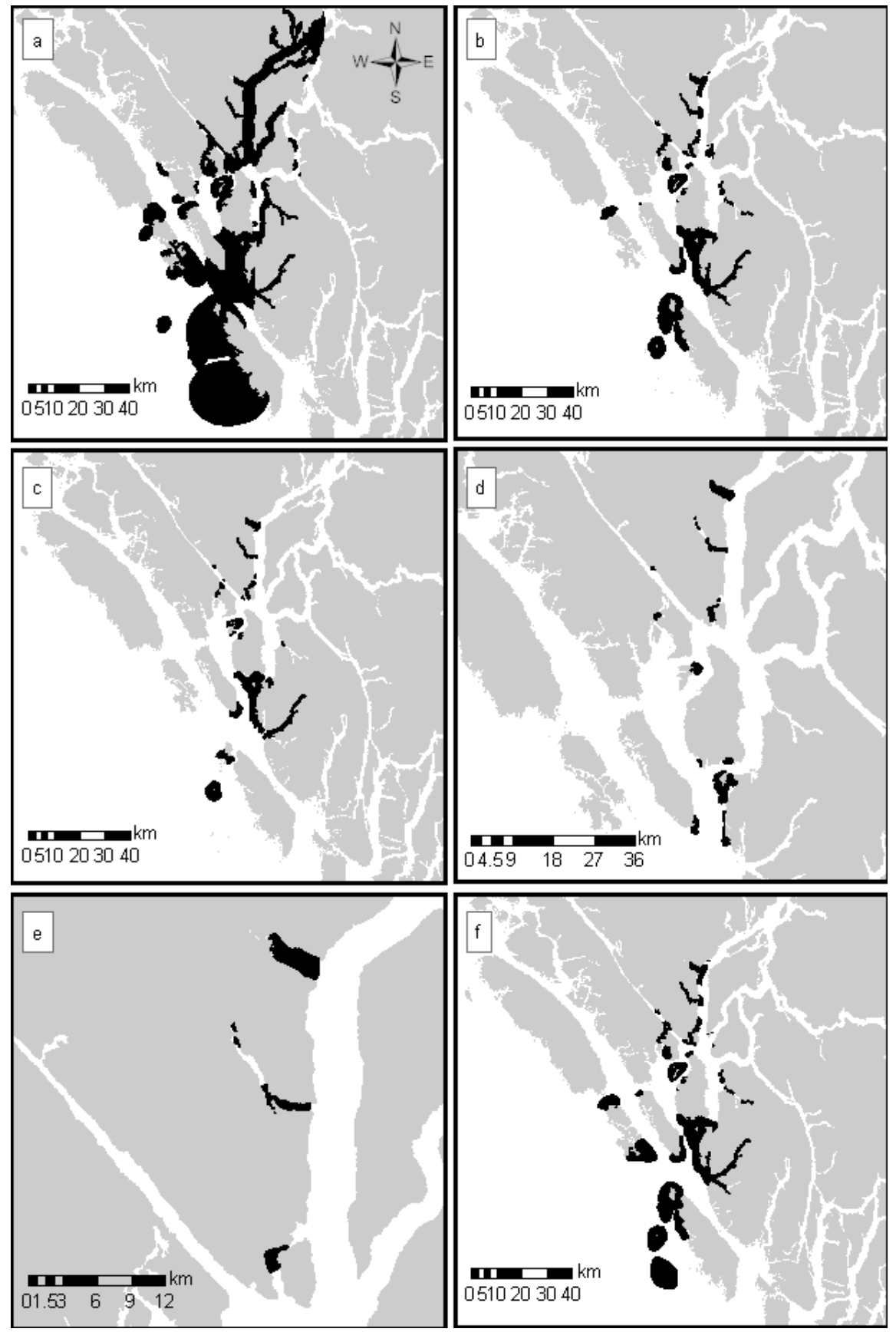
Fig. 5. Huu-ay-aht case study: four scenarios were created from individual interviews for the most common protection type where only aboriginal rights fisheries would be allowed: "a" all areas selected by any participant; "b" areas selected by $20 \%$ of participants; "c" areas selected by $30 \%-50 \%$ of participants; and "d" areas selected by $>50 \%$ of participants. No areas were areas selected by all participants. "b" was most preferred by participants at the feedback meeting. The areas noted on the map reflect participants' interpretations of the traditional territory.
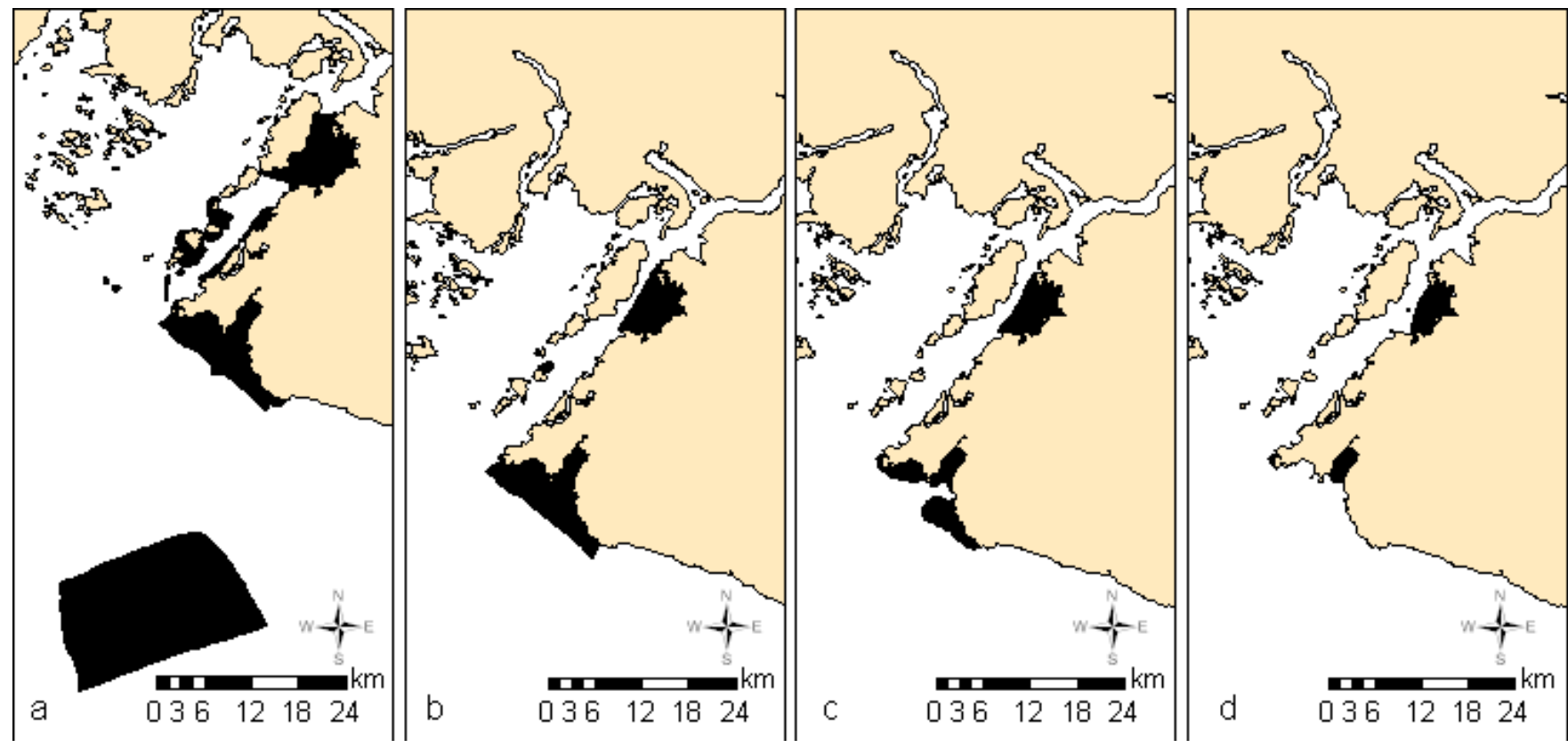

both communities. The common goals likely reflect the ongoing reliance of BC coastal First Nations on traditional foods, especially seafood, to supplement their diet (Weinstein and Morrell 1994). These foods are also an integral part of indigenous culture (Garibaldi and Turner 2004). The goals expressed by participants are very similar to conservation and ecosystem-based management objectives of ensuring the persistence and representation of species (Margules and Pressey 2000), and allowing for sustainable fisheries (Pikitch et al. 2004).

The apparent emphasis on conservation by participants also incorporates other issues. In particular, by suggesting the exclusion of commercial and recreational fishermen from their historical fishing areas, participants are hoping to assume some control over the use and management of these areas. Their suggestions entail implementation of aboriginal rights in a conservation context. This can be interpreted as an attempt by participants to manage common-pool resources by excluding other users (Ostrom et al. 1999). Also, participants commented on the decline of many species within their territories, notably abalone, salmon, groundfish, herring, and eulachon. These declines have been happening with the federal and provincial governments as the managing authorities (e.g., Slaney et al. 1996). The resulting lack of confidence in the current management of marine resources is likely another factor contributing to a desire by participants to be involved in the management of marine resources in their territories. Given their local knowledge of the trends in marine species, participants noted frustrations in observing declines without being able to assist in managing for recovery.

Not many participants mentioned access to commercial fishing opportunities as a priority when asked about their vision for the future. This omission is interesting given that both communities used to 
Table 3. Overlap of preferred protection areas and commercial fisheries for which spatial catch data are available.

\begin{tabular}{|c|c|c|c|c|c|c|}
\hline \multicolumn{3}{|c|}{ Fisheries and Oceans Canada fishing data layer } & \multicolumn{2}{|c|}{$\begin{array}{l}\text { Gitga' at area commercial catches } \\
\text { within preferred protection areas }\end{array}$} & \multicolumn{2}{|c|}{$\begin{array}{l}\text { Huu-ay-aht area commercial } \\
\text { catches within preferred } \\
\text { protection areas }\end{array}$} \\
\hline Fishery & Grid size & Years & $\mathrm{lbs} / \mathrm{yr}$ & $\begin{array}{l}\% \text { of catches } \\
\text { within the } \\
\text { territory }\end{array}$ & lbs/yr & $\begin{array}{l}\% \text { of catches } \\
\text { within the } \\
\text { territory }\end{array}$ \\
\hline Crabs & $4 \mathrm{~km}$ & 2000-2004 & 1744.9 & $7.8 \%$ & 1298.8 & $11.9 \%$ \\
\hline Geoduck & $10 \mathrm{~km}$ & $2002-2004$ & 29015.7 & $10.2 \%$ & 856.9 & $17.0 \%$ \\
\hline Groundfish trawl & $4 \mathrm{~km}$ & 1996-2004 & 0.0 & $0.0 \%$ & 0.0 & $0.0 \%$ \\
\hline Prawn & $4 \mathrm{~km}$ & 2001-2004 & 3586.5 & $7.5 \%$ & 8236.9 & $22.4 \%$ \\
\hline Red urchins & $10 \mathrm{~km}$ & $1997-2003$ & 486425.5 & $14.9 \%$ & 2378.5 & $14.0 \%$ \\
\hline Sablefish trap & $4 \mathrm{~km}$ & 1996-2004 & 334.1 & $15.4 \%$ & 0.0 & $0.0 \%$ \\
\hline Sablefish longline & $4 \mathrm{~km}$ & 1996-2004 & 0.0 & $0.0 \%$ & 0.0 & $0.0 \%$ \\
\hline $\begin{array}{l}\text { Schedule } 2 \text { (hook and } \\
\text { line) }\end{array}$ & $4 \mathrm{~km}$ & 1996-2004 & 239.9 & $1.5 \%$ & 0.0 & $0.0 \%$ \\
\hline Sea cucumber & $10 \mathrm{~km}$ & 1997-2004 & 49343.1 & $10.0 \%$ & N/A & N/A \\
\hline Shrimp trawl & $4 \mathrm{~km}$ & 1996-2004 & 0.0 & $0.0 \%$ & 5472.6 & $0.1 \%$ \\
\hline $\mathrm{ZN}$ (hook and line) & $4 \mathrm{~km}$ & 1993-2004 & 4877.1 & $7.1 \%$ & 185.3 & $5.2 \%$ \\
\hline Total & & & 575566.8 & $7.4 \%$ & 18429.0 & $7.1 \%$ \\
\hline
\end{tabular}

be engaged in commercial fisheries, yet very few people remain involved. Also, fishing for food is expensive in the case study areas, requiring at a minimum boat and gear maintenance, and fuel; commercial fisheries could be seen as a means to subsidize indigenous fishing. The limited mention of commercial fisheries by participants could be explained in several ways. First, it could also be that the local resource depletions noted by participants suggest to them that commercial fisheries may not be a viable option. Second, recent development emphasis in both communities has been on shellfish aquaculture, perhaps decreasing the perceived importance of commercial fisheries. Third, it is also possible that participants perceived the commercial fishery issue as being pursued through other means, and hence did not think to mention it during the interviews. For instance, the Huu-ay-aht First Nation is part of the Maa-nulth treaty that is currently under negotiation. The harvest agreement of the Maa-nulth treaty includes long-term, guaranteed, and renewable commercial fishing privileges for Maa-nulth First Nations to a defined share of the commercial catch (Indian and Northern Affairs Canada 2007). The Gitga' at First Nation has several successful participants in the commercial salmon and groundfish fisheries. They are currently using this core of fishing capacity to incrementally increase community participation in these and other fisheries. They are also seeking additional acquisition of commercial fishing assets (i.e., licenses, quotas, and equipment) through partnerships with other First Nations, governments, and private interests. Finally, the conservation focus 
of most of our questions may have had the unintended consequence of discouraging responses that might imply increased fishing effort.

In considering the proposals made by First Nations' respondents, it is important to note that most were involved in either commercial or sport fishing, the very activities they suggest should be excluded from the protected areas. Their insistence on allowing only aboriginal fisheries in some areas was, therefore, not just self-serving. Many of the aboriginal commercial fishers interviewed stated that they would be happy to avoid the preferred protection areas when fishing commercially. It does seem, however, that First Nations people would benefit the most from the suggested protection measures. Commercial fisheries, for example, would be displaced approximately proportionally to the area protected.

The two First Nations agreed on the most important protective measures, but the Gigta' at selected more areas. Such a difference might be associated with the longer, more complex coastline in the Gitga' at territory, or their ongoing use of seasonal camps widely scattered across the territory. When considering the inshore areas, the percentage of the Gitga'at territory selected as preferred protected areas $(15 \%)$ exceeds the $10 \%$ goal of the Convention on Biological Diversity (CBD) (2006), but falls short of the $20 \%$ to $50 \%$ commonly suggested in the scientific literature (Plan Development Team 1990, Dahlgren and Sobel 2000, Roberts et al. 2003b, Parnell et al. 2006, Stewart et al. 2007). The Huuay-aht case study falls short in reaching any of these targets. The differences in the number of areas selected emphasizes that each local context will provide its own solutions.

The preferred scenarios discussed at the feedback meetings were not those that had the most overlap, but rather those that covered a larger-but not the largest - area. Although our focus was not on the dynamics that occurred at the feedback sessions, we observed that no one person dominated the meetings. Participants included hereditary chiefs, however, and tradition dictates that they are allowed to speak before others. It did not seem to us that this tradition prevented others from speaking up, but perhaps further study of the dynamics in such meetings in indigenous communities is warranted.

The specifics of how the MPAs suggested by participants might be managed, and the rules of engagement, were not the focus or our work. Should the First Nations seek to pursue the establishment of such MPAs, setting out some rules of how these areas might be managed will be very important. Many participants mentioned the importance of the First Nations having a lead or key role in the management of these areas. Co-management was mentioned many times as an important concept. Also, the rules of engagement would need to be very clear. For example, what activities would be excluded, and which ones would be allowed? In our interviews, we focused on getting participants' suggestions for marine management, rather than setting out such a set of rules.

If the community-preferred areas are to serve as the backbone of a MPA network, then those areas should be analyzed for representation of habitats and species. Systematic conservation planning emphasizes that all ecosystem components should be represented in a protected area network (Margules and Pressey 2000). If the local goal is to recover depleted species, then those species and their habitats have to be included in the network. Decision support tools such as Marxan (Ball and Possingham 2000, Possingham et al. 2000) can be used to assist in planning to ensure representation. The community-preferred areas can be used as the core for building such a network.

The goals of First Nations, and those outlined in MPA theory (e.g., Roberts et al. 2003a) follow similar themes, but are not the same. The main difference is that MPA theory emphasizes representation (Margules and Pressey 2000, Roberts et al. 2003a), which was not mentioned by participants. Through the principle of representation, MPA theory values all species and habitats, and recommends their inclusion in MPAs. First Nations, on the other hand, may value some species more than others (e.g., Garibaldi and Turner 2004), and therefore, may focus conservation efforts on those species. However, the indigenous worldview of "everything is one" is prevalent amongst many First Nations in British Columbia (e.g., Atleo 2004). This worldview recognizes the importance and interconnectedness of all ecosystem components.

One of the limitations of following recommendations from participants is that effective conservation tools may be missed. For example, in our case studies, few people suggested no-take areas, which have much more scientific evidence of success than partially protected areas (Hutchings 2000, 
Murawski et al. 2000). We did not specify the type of protection when interviewing participants. As a next step, it would be possible to use the communitypreferred areas as the basis for a network of MPAs and then add other types of zones, such as no-take areas, to strengthen the network. This could be done either through additional interviews with community members and through community meetings, or by using a decision support tool such as Marxan. Our discussions with participants suggest that there may be support for no-take areas once a basic set of aboriginal fishing areas have been protected. Some participants commented that notake areas should not be located in important traditional fishing areas, and that First Nations communities should have a say in where no-take zones should be placed. Indeed, Canadian governments have a legal obligation to consult and accommodate before making such a decision (Harris 2002).

The scientific literature places emphasis on no-take MPAs (Ballantine 1995, Dayton et al. 2000, Halpern and Warner 2002, Botsford et al. 2003, Gell and Roberts 2003, Roberts et al. 2003a, 2003b), yet the spatial management option preferred by indigenous people interviewed for this study was to allow indigenous extraction for food, social, and ceremonial purposes to continue. As the Biodiversity Convention and many national laws declare that aboriginal rights must be respected, where does the future lie for no-take MPAs? One route may lie in engaging First Nations in extended talks on the merits of no-take MPAs, which are already of potential interest to some of our respondents. However, given the past history of First Nations' opposition to no-take zones (Ayers 2005, Guenette and Alder 2007), it would also be logical to develop a category of protection that permits indigenous extraction for food. Such MPAs are being pursued in the Canadian Arctic (Berkes et al. 2007). The International Union for Conservation of Nature (IUCN) categories for parks include a sustainable use category (Phillips 2003), which could be adopted for the marine environment.

However, the effectiveness of such partially closed marine areas has not been studied extensively, and their efficacy compared with no-take areas is debated (Ballantine 1995, 1999, Agardy et al. 2003). Some researchers suggest that certain types of partially protected areas may provide similar benefits to fully closed areas (Ley et al. 2002, McClanahan et al. 2006), but others disagree
(Hutchings 2000, Murawski et al. 2000). If other extractive activities are prohibited in such areas, then the reduced total extraction should result in conservation benefits as well. Such aboriginal fishing zones certainly have the support of participants in our research, and hence may provide a solution to the slow pace of MPA establishment. User groups would need to be supportive as well, and just compensation would be necessary. Further research is urgently needed to identify the conservation effectiveness of zones where limited extraction is allowed to continue.

\section{CONCLUSION}

Marine protection is a controversial topic in British Columbia and elsewhere in the world (LeRoy 2002, Ayers 2005), and the engagement by indigenous people in this research and the success of the framework was by no means certain. Our threephased framework was very well received by participants, and may be a promising approach for other communities. All three phases were important in the success of our project:

- Developing research partnerships, including data-sharing agreements, clearly laid out the objectives of our work, determined how we would partner with the First Nations, and served to develop a level of trust in our partnership. The data-sharing arrangement was perhaps the most important aspect of our work, as it allowed the First Nations partners to retain control of the information and how to use it in the future. Setting up partnerships can be very time consuming, as are individual interviews. If indigenous groups carry out such research and marine planning themselves, however, then the long process of building partnerships would be superfluous.

- The advantage of the individual interviews was that they allowed us to build individual relationships with participants, and they encouraged participants to express their own goals and issues, and suggest management actions. The disadvantage of the individual interviews was that they are time intensive. However, given the importance of participation (Kessler 2003, 2004, Dalton 2005), the additional time investment may be worthwhile for achieving greater engagement. 
- The community meetings provided an opportunity for interview participants and others to see the results of the study and provide feedback. Community meetings alone, however, have been criticized for incorporating only the opinions of the loudest and most outspoken participants (Petts and Leach 2000).

The suitability of participants' suggestions in addressing local issues, and the apparent willingness of participants to forgo some personal benefits to achieve their goal, emphasizes the importance of eliciting perceptions of issues and encouraging locally appropriate solutions. We found strong support for spatial protection measures among participants. Our study highlights a gap in our current conservation approaches: the conservation of areas that are important to indigenous people, where they can continue to practice and adapt their culture.

Responses to this article can be read online at:

http://www.ecologyandsociety.org/voll3/iss 1/art32/responses/

\section{Acknowledgments:}

We would like to extend a sincere thank-you to all participants in this research, and to both the Gitga'at and Huu-ay-aht First Nations for their research partnerships. Stefan Ochman, our liaison with the Huu-ay-aht First Nation, and Teri Robinson and Kyle Clifton with the Gitga'at First Nation, deserve special recognition for their assistance in our research. Colleagues at Project Seahorse provided helpful comments on previous drafts; particular thanks to Maï Yasué for extensive suggestions. For this work, NCB received funding from The Canon National Parks Science Scholars Program, the Mountain Equipment Co-operative studentship, the Ocean Management Research Network, and the Natural Sciences and Engineering Research Council of Canada. AV received support from the John G. Shedd Aquarium and Chocolaterie Guylian.

\section{LITERATURE CITED}

Abesamis, R., and G. Russ. 2005. Densitydependent spillover from a marine reserve: longterm evidence. Ecological Applications 15:17981812.

Agardy, T., P. Bridgewater, M. P. Crosby, J. Day, P. K. Dayton, R. Kenchington, D. Laffoley, P. McConney, P. S. Murray, J. E. Parks, and L. Peau. 2003. Dangerous targets? Unresolved issues and ideological clashes around marine protected areas. Aquatic Conservation: Marine and Freshwater Ecosystems 13:353-367.

Ardron, J. 2005. Quantifying local knowledge for use in marine planning: a pilot project in British Columbia's South Central Coast. Thesis, Royal Roads University, Victoria, British Columbia, Canada.

Atleo, E. R. 2004. Tsawalk: a Nuu-chah-nulth worldview. UBC Press, Vancouver, British Columbia, Canada.

Ayers, C.A. 2005. Marine conservation from a First Nations'perspective: a case study of the principles of the Hul'quimi'num of Vancouver Island, British Columbia. Thesis, University of Victoria, Victoria, British Columbia, Canada.

Ball, I. R., and H. Possingham. 2000. Marxan (V1.8.2): marine reserve design using spatially explicit annealing, a manual. [online] URL: http:// www.uq.edu.au/marxan/docs/marxan manual 182. pdf.

Ballantine, B. 1995. Networks of "no-take" marine reserves are practical and necessary. Pages 13-20 in N. L. Shackell and J. H. M. Willison, editors. Marine protected areas and sustainable fisheries. Science and Management of Protected Areas Association, Wolfville, Nova Scotia, Canada. [online] URL: http://www.marine-reserves.org.nz/p apers/concept.pdf.

Ballantine, B. 1999. Marine reserves in New Zealand: the development of the concept and the principles. Pages 3-38 in International Workshop on Marine Conservation for the New Millenium. Korean Ocean Research and Development Institute, Cheju Island, Korea. 
Ban, N., and J.Alder. 2008. How wild is the ocean? Assessing the intensity of anthropogenic marine activities in British Columbia, Canada. Aquatic Conservation: Marine and Freshwater Ecosystems 18:55-85. DOI: 10.1002/aqc.816.

Berkes, F., M. K. Berkes, and H. Fast. 2007. Collaborative integrated management in Canada's North: the role of local and traditional knowledge and community-based monitoring. Coastal Management 35:143-162.

Berkes, F., J. Colding, and C. Folke. 2000. Rediscovery of traditional ecological knowledge as adaptive management. Ecological Applications 10:1251-1262.

Bess, R. 2001. New Zealand's indigenous people and their claims to fisheries resources. Marine Policy 25:23-32.

Botsford, L. W., F. Micheli, and A. Hastings. 2003. Principles for the design of marine reserves. Ecological Applications 13:S25-S31.

Brody, S., D. Godschalk, and R. Burby. 2003. Mandating citizen participation in plan making: six strategic planning choices. Journal of the American Planning Association 69:245-265.

Convention on Biological Diversity (CBD). 2006. Decisions adopted by the Conference of the Parties to the Convention on Biological Diversity at its eighth meeting (Decision VIII/15, Annex IV). Convention on Biological Diversity, Curitiba, Brazil.

Dahlgren, C. P., and J. Sobel. 2000. Designing a dry tortugas ecological reserve: how big is big enough?... to do what? Bulletin of Marine Science 66:707-719.

Dalton, T. M. 2005. Beyond biogeography: a framework for involving the public in planning of U.S. marine protected areas. Conservation Biology 19:1392-1401.

Davis, A., and S. Jentoft. 2001. The challenge and the promise of indigenous peoples' fishing rightsfrom dependency to agency. Marine Policy 25:223237.

Dayton, P. K., E. Sala, M. J. Tegner, and S. Thrush. 2000. Marine reserves: parks, baselines, and fishery enhancement. Bulletin of Marine Science 66:617-634.

Drew, J. A. 2005. Use of traditional ecological knowledge in marine conservation. Conservation Biology 19:1286-1293.

Fast, H., J. Mathias, and O. Banias. 2001. Directions toward marine conservation in Canada's Western Arctic. Ocean and Coastal Management 44:183-205.

Fisheries and Oceans Canada. 2008. Aboriginal fisheries strategy. Fisheries and Oceans Canada, Ottawa, Ontario, Canada. [online] URL: http://ww w.pac.dfo-mpo.gc.ca/tapd/afs e.htm.

Garibaldi, A., and N. Turner. 2004. Cultural keystone species: implications for ecological conservation and restoration. Ecology and Society 9(3): 1. [online] URL: http://www.ecologyandsociety. org/vol9/iss3/art1/.

Gell, F. R., and C. M. Roberts. 2003. The fishery effects of marine reserves and fishery closures. World Wildlife Fund - U.S., Washington, D.C., USA.

Getis, A., and K. Ord. 1992. The analysis of spatial association by the use of distance statistics. Geographical Analysis 24:189-206.

Goodman, L. 1961. Snowball sampling. The Annals of Mathematical Statistics 32:148-170.

Guenette, S., and J. Alder. 2007. Lessons from marine protected areas and integrated ocean management initiatives in Canada. Coastal Management 35:51-78.

Halpern, B. S., S. D. Gaines, and R. R. Warner. 2004. Confounding effects on the export of production and the displacement of fishing effort from marine reserves. Ecological Applications 14:1248-1256.

Halpern, B. S., and R. R. Warner. 2002. Marine reserves have rapid and lasting effects. Ecology Letters 5:361-366.

Harris, D. C. 2001. Fish, law, and colonialism: the legal capture of salmon in British Columbia. University of Toronto Press, Toronto, Ontario, Canada. 
Harris, R. 2002. Making native space: colonialism, resistance, and reserves in British Columbia. UBC Press, Vancouver, British Columbia, Canada.

Helvey, M. 2004. Seeking consensus on designing marine protected areas: keeping the fishing community engaged. Coastal Management 32:173190.

Hilborn, R., F. Micheli, and G. A. De Leo. 2006. Integrating marine protected areas with catch regulation. Canadian Journal of Fisheries and Aquatic Sciences 63:642-649.

Houde, N. 2007. The six faces of traditional ecological knowledge: challenges and opportunities for Canadian co-management arrangements. Ecology and Society 12(2):34. [online] URL: http:/ /www.ecologyandsociety.org/vol12/iss2/art34/.

Hutchings, J. A. 2000. Collapse and recovery of marine fishes. Nature 406:882-885.

Indian and Northern Affairs Canada. 2007. Maanulth final agreement: fisheries. [online] URL: htt p://www.ainc-inac.gc.ca/bc/treapro/ston/fnagr/mna/ fsh e.html.

Innes, J. 1996. Planning through consensus building. Journal of the American Planning Association 62:460-472.

Kay, R., and J. Alder. 2005. Coastal management and planning. Second edition. Taylor and Francis, New York, New York, USA.

Kelleher, G., and R. A. Kenchington. 1992. Guidelines for establishing marine protected areas: a marine conservation and development report. International Union for Conservation of Nature (IUCN), Gland, Switzerland.

Kessler, B. L. 2003. Marine protected area (MPA) process review: case studies of five MPA establishment processes. National Marine Protected Areas Center, National Oceanic and Atmospheric Administration (NOAA) Coastal Services Center, Charleston, South Carolina, USA.

Kessler, B. L. 2004. Stakeholder participation: a synthesis of current literature. NOAA, Silver Spring, Maryland.

LeRoy, S. 2002. Public process and the creation of a marine protected area at Race Rocks, British Columbia. University of British Columbia, Vancouver, British Columbia, Canada. [online] URL: http://www3.telus.net/LeRoy/Portfolio/10b_leroy. pdf.

LeRoy, S., R. Dobell, T. Dorcey, and J. Tansey. 2003. Public process and the creation of the Race Rocks Marine Protected Area. Pages 1-12 in Georgia Basin/Puget Sound Research Conference.

Ley, J. A., I. A. Halliday, A. J. Tobin, R. N. Garrett, and N. A. Gribble. 2002. Ecosystem effects of fishing closures in mangrove estuaries of tropical Australia. Marine Ecology Progress Series 245:223-238.

Lundquist, C. J., and E. F. Granek. 2005. Strategies for successful marine conservation: integrating socioeconomic, political, and scientific factors. Conservation Biology 19:1771-1778.

Margules, C. R., and R. L. Pressey. 2000. Systematic conservation planning. Nature 405:243253.

Mascia, M. B. 2003. The human dimension of coral reef marine protected areas: recent social science research and its policy implications. Conservation Biology 17:630-632.

Matell, M., and J. Jacoby. 1971. Is there an optimal number of alternatives for Likert scale items? Study I: reliability and validity. Educational and Psychological Measurement 31:657.

McClanahan, T., and S. Mangi. 2000. Spillover of exploitable fishes from a marine park and its effect on the adjacent fishery. Ecological Applications 10:1792-1805.

McClanahan, T. R., M. J. Marnane, J. E. Cinner, and W. E. Kiene. 2006. A comparison of marine protected areas and alternative approaches to coralreef management. Current Biology 16:1408-1413.

Menzies, C. R., C. F. Butler, and E. Developments. 2001. Working in the woods. The American Indian Quarterly 25:409-430.

Morin Dalton, T. 2001. Sanctuary advisory councils: involving the public in the National Marine Sanctuary program. Coastal Management 37:327-339. 
Mulrennan, M., and C. Scott. 2000. Mare Nullius: indigenous rights in saltwater environments. Development and Change 31:681-708.

Mulrennan, M., and C. Scott. 2001. Indigenous rights and control of the sea in Torres Strait. Indigenous Law Bulletin 5:11-15.

Murawski, S. A., R. Brown, H.-L. Lai, P. J. Rago, and L. Hendrickson. 2000. Large-scale closed areas as a fishery-management tool in temperate marine systems: the Georges Bank experience. Bulletin of Marine Science 66:775-798.

Ostrom, E., J. Burger, C. B. Field, R. B. Norgaard, and D. Policansky. 1999. Revisiting the commons: local lessons, global challenges. Science 284:278-282.

Parnell, P. E., P. K. Dayton, C. E. Lennert-Cody, L. L. Rasmussen, and J. J. Leichter. 2006. Marine reserve design: optimal size, habitats, species affinities, diversity, and ocean microclimate. Ecological Applications 16:945-962.

Pauly, D., V. Christensen, J. Dalsgaard, R. Froese, and F. Torres, Jr. 1998. Fishing down marine food webs. Science 279:860-863.

Petts, J., and B. Leach. 2000. Evaluating methods for public participation: literature review. Technical Report E135. Environment Agency, Bristol, UK. pp. 1-74. [online] URL: http://www.corwm.org.uk/ pdf\%5C0549\%20\%20-\%20litrev 1.pdf.

Phillips, A. 2003. Turning ideas on their head: the new paradigm for protected areas. The George Wright Forum 20:8-32.

Pikitch, E. K., C. Santora, E. A. Babcock, A. Bakun, R. Bonfil, D. O. Conover, P. Dayton, P. Doukakis, D. Fluharty, B. Heneman, E. D. Houde, J. Link, P. A. Livingston, M. Mangel, M. K. McAllister, J. Pope, and K. J. Sainsbury. 2004. ECOLOGY: Ecosystem-Based Fishery Management Ecosystem-based fishery management. Science 305:346-347.

Plan Development Team. 1990. The potential of marine fishery reserves for reef fish management in the U.S. southern Atlantic. NOAA technical memorandum NMFS-SEFC-261, Springfield, Virginia, USA.
Possingham, H. P., I. R. Ball, and S. Andelman. 2000. Mathematical methods for identifying representative reserve networks. Pages 291-305 in S. Ferson and M. Burgman, editors. Quantitative methods for conservation biology. Springer-Verlag, New York, New York, USA.

Roberts, C. M., S. Andelman, G. Branch, R. H. Bustamente, J. C. Castilla, J. Dugan, B. S. Halpern, K. D. Lafferty, H. Leslie, J. Lubchenco, D. McArdle, H. P. Possingham, M. Ruckelshaus, and R. R. Warner. 2003a. Ecological criteria for evaluating candidate sites for marine reserves. Ecological Applications 13:S199-S214.

Roberts, C. M., G. Branch, R. H. Bustamente, J. C. Castilla, J. Dugan, B. S. Halpern, K. D. Lafferty, H. Leslie, J. Lubchenco, D. McArdle, M. Ruckelshaus, and R. R. Warner. 2003b. Application of ecological criteria in selecting marine reserves and developing reserve networks. Ecological Applications 13:S215-S228.

Ross, A., and K. Pickering. 2002. The politics of reintegrating Australian Aboriginal and American Indian indigenous knowledge into resource management: the dynamics of resource appropriation and cultural revival. Human Ecology 30:187-214.

Salm, R. V., and J. R. Clark. 2000. Marine and coastal protected areas, a guide for planners and managers, Third edition. IUCN, Cambridge, UK.

Sanders, W. 2002. Towards an Indigenous order of Australian government: rethinking self-determination as Indigenous affairs policy. 230/2002, Australian National University, Canberra, Australia.

Slaney, T. L., K. D. Hyatt, T. G. Northcote, and R. J. Fielden. 1996. Status of anadromous salmon and trout in British Columbia and Yukon. Fisheries 21:20-35.

Stewart, R. R., I. R. Ball, and H. P. Possingham. 2007. The effect of incremental reserve design and changing reservation goals on the long-term efficiency of reserve systems. Conservation Biology 21:346-354.

United Nations General Assembly. 2007. United Nations declaration on the rights of indigenous peoples. A/RES/61/295, United Nations, New York, New York, USA. 
Walters, C. 1998. Designing fisheries management systems that do not depend upon accurate stock assessment. Pages 279-288 in T. J. Pitcher, P. J. B. Hart, and D. Pauly, editors. Reinventing fisheries management. Kluwer Academic Publishers, London, UK.

Walters, C. 2000. Impacts of dispersal, ecological interactions, and fishing effort dynamics on efficacy of marine protected areas: how large should protected areas be? Bulletin of Marine Science 66:745-757.

Weinstein, M. P., R. C. Baird, D. O. Conover, M. Gross, J. Keulartz, D. K. Loomis, Z. Naveh, S. B. Peterson, D. J. Reed, and E. Roe. 2007. Managing coastal resources in the 21 st century. Frontiers in Ecology and the Environment 5:43-48.

Weinstein, M. S., and M. Morrell. 1994. Need is not a number: report of the Kwakiutl marine food fisheries Reconnaissance survey. Kwakiutl Territorial Fisheries Commission, Campbell River, British Columbia, Canada.

Wood, L. J., L. Fish, J. Laughren, and D. Pauly. 2007. Assessing progress towards global marine protection targets: shortfalls in information and action. UBC Fisheries Centre Working Paper Series \#2007-03:1-39.

World Summit on Sustainable Development. 2003. World summit on sustainable development plan of implementation (oceans section). World Summit on Sustainable Development, 26 August4 September 2002, Johannesberg, South Africa.

Worm, B., E. B. Barbier, N. Beaumont, J. E. Duffy, C. Folke, B. S. Halpern, J. B. C. Jackson, H. K. Lotze, F. Micheli, S. R. Palumbi, E. Sala, K. A. Selkoe, J. J. Stachowicz, and R. Watson. 2006. Impacts of Biodiversity Loss on Ocean Ecosystem Services. Science 314:787-790.

Zaferatos, N. C. 2004. Tribal nations, local governments, and regional pluralism in Washington State: The Swinomish approach in the Skagit Valley. Journal of the American Planning Association 70:81-97. 